\title{
New insights into biometeorology
}

\author{
Simon N. Gosling
}

Published online: 25 January 2014

(C) ISB 2014

This special issue presents a series of 16 articles led by members of the Students and New Professionals (SNP) group of the International Society of Biometeorology (ISB). The SNP group includes almost 50 active members who are either within 5 years from leaving education (e.g. $\mathrm{PhD}$ study) or under 35 years of age. The group first met together at the 18 th International Congress of Biometeorology (ICB) in Tokyo, September 2008 and for a second time at the 19th ICB in Auckland, December 2011. At the 19th ICB the group agreed to submit a series of articles for consideration for publication in a special issue of International Journal of Biometeorology. This issue of the journal serves to disseminate the articles that were submitted and accepted for publication, and also to highlight the latest biometeorological insights from this group of the ISB.

Biometeorology is an extensive study area (McGregor 2012) and this is demonstrated by the diversity of studies in the special issue, which include several of the "fields" covered by the journal and for which there are dedicated Field Editors (Beggs 2013). In the order in which they appear in the issue, these fields include: phenology (Hanes 2012); climate change and public health (Hondula et al. 2013; Vanos and Cakmak 2013; Cheung and Hart 2012; Sujaritpong et al. 2013); urban biometeorology (Park and Tuller 2013); animals (de Melo Costa et al. 2013; Luo et al. 2013; Nascimento et al. 2013); and epidemiology (Tawatsupa et al. 2012; Allen and Sheridan 2013; Burkart et al. 2013; Xu et al. 2013; Wanka et al. 2013; Jacobs et al. 2013).

The articles also reflect the international diversity of the SNP membership, with articles that describe biometeorological research conducted in Australia (Jacobs et al. 2013), Bangladesh (Burkart et al. 2013), Brazil (de Melo Costa

S. N. Gosling $(\bowtie)$

School of Geography, University of Nottingham, Nottingham, UK e-mail: Simon.Gosling@nottingham.ac.uk et al. 2013), Canada (Vanos and Cakmak 2013; Park and Tuller 2013), Germany (Wanka et al. 2013), Hong Kong (Cheung and Hart 2012), Republic of Korea (Park and Tuller 2013), Thailand (Tawatsupa et al. 2012), and the United States (Hanes 2012; Allen and Sheridan 2013).

The final article published in this special issue is a glossary for biometeorology (Gosling et al. 2014), which represents the output of the SNP group members' main joint research project since the 18th ICB. It is the first published glossary of biometeorological terms and it brings together the expertise and efforts of our diverse, dynamic and integrated group.

I have been privileged to Chair the SNP group since late 2009 (Gosling 2010) and I have enjoyed observing the activities of the group grow rapidly over the past 5 years. Collaboration across the SNP group continues to develop and with the generous support of the Tromp Foundation and the ISB we have started work on our next SNP group project, which aims to assess current weather-health relationships in cities in India, Russia and New Zealand. The first outcomes related to this project are presented in this issue (Hondula et al. 2013). We are also organising a 1-day workshop, which all SNP group members are invited to attend, at Kent State University on 28th September 2014, at the start of the 20th ICB in Cleveland, USA.

\section{References}

Allen M, Sheridan S (2013) High-mortality days during the winter season: comparing meteorological conditions across 5 US cities. Int J Biometeorol:1-9. doi:10.1007/s00484-013-0640-4

Beggs P (2013) Climate change and biometeorology, the International Society of Biometeorology and its journal: a perspective on the past and a framework for the future. Int J Biometeorol 5:1-6

Burkart K, Breitner S, Schneider A, Khan MM, Krämer A, Endlicher W (2013) An analysis of heat effects in different subpopulations of 
Bangladesh. Int J Biometeorol:1-11. doi:10.1007/s00484-0130668-5

Cheung C, Hart M (2012) Climate change and thermal comfort in Hong Kong. Int J Biometeorol:1-12. doi:10.1007/s00484-012-0608-9

de Melo Costa CC, Maia ASC, Neto JDF, Oliveira SEO, Queiroz JPAF (2013) Latent heat loss and sweat gland histology of male goats in an equatorial semi-arid environment. Int J Biometeorol:1-6. doi:10. 1007/s00484-013-0642-2

Gosling SN (2010) ISB News January 2010. Int J Biometeorol 54:113113. doi:10.1007/s00484-009-0297-1

Gosling SN, Bryce EK, Dixon PG, Gabriel KMA, Gosling EY, Hanes JM, Hondula DM, Liang L, Bustos Mac Lean PA, Muthers S, Nascimento ST, Petralli M, Vanos JK, Wanka ER (2014) A glossary for biometeorology. Int J Biometeorol:1-33. doi:10.1007/s00484013-0729-9.

Hanes J (2012) Spring leaf phenology and the diurnal temperature range in a temperate maple forest. Int J Biometeorol:1-6. doi:10.1007/ s00484-012-0603-1

Hondula DM, Vanos JK, Gosling SN (2013) The SSC: a decade of climate-health research and future directions. Int J Biometeorol:112. doi: 10.1007/s00484-012-0619-6

Jacobs S, Pezza A, Barras V, Bye J (2013) A new 'bio-comfort' perspective for Melbourne based on heat stress, air pollution and pollen. Int J Biometeorol:1-13. doi:10.1007/s00484-013-0636-0

Luo B, Zhang S, Ma S, Zhou J, Wang B (2013) Effects of different coldair exposure intensities on the risk of cardiovascular disease in healthy and hypertensive rats. Int J Biometeorol:1-10. doi:10. 1007/s00484-013-0641-3
McGregor GR (2012) Human biometeorology. Progress in Physical Geography 36:93-109. doi:10.1177/0309133311417942

Nascimento S, Silva I, Maia A, Castro A, Vieira F (2013) Mean surface temperature prediction models for broiler chickens - a study of sensible heat flow. Int J Biometeorol:1-7. doi:10.1007/s00484013-0702-7

Park S, Tuller S (2013) Advanced view factor analysis method for radiation exchange. Int J Biometeorol:1-18. doi:10.1007/s00484013-0657-8.

Sujaritpong S, Dear K, Cope M, Walsh S, Kjellstrom T (2013) Quantifying the health impacts of air pollution under a changing climate- a review of approaches and methodology. Int $\mathrm{J}$ Biometeorol:1-12. doi:10.1007/s00484-012-0625-8

Tawatsupa B, Dear K, Kjellstrom T, Sleigh A (2012) The association between temperature and mortality in tropical middle income Thailand from 1999 to 2008. Int J Biometeorol:1-13. doi:10.1007/ s00484-012-0597-8

Vanos JK, Cakmak S (2013) Changing air mass frequencies in Canada: potential links and implications for human health. Int J Biometeorol: 1-15. doi:10.1007/s00484-013-0634-2

Wanka ER, Bayerstadler A, Heumann C, Nowak D, Jörres RA, Fischer R (2013) Weather and air pollutants have an impact on patients with respiratory diseases and breathing difficulties in Munich, Germany. Int J Biometeorol:1-14. doi:10.1007/ s00484-013-0730-3

Xu Z, Sheffield P, Su H, Wang X, Bi Y, Tong S (2013) The impact of heat waves on children's health: a systematic review. Int J Biometeorol: 1-9. doi:10.1007/s00484-013-0655-x 